\title{
Pendampingan Pemasaran Melalui Perbaikan Kemasan Produk Makanan Ringan Pengusaha Kecil di Semarang Utara
}

\author{
Samuel Bintang Nugroho, Marino Adhityawan, Dwi Hayu Agustini \\ Program Studi Manajemen, Fakultas Ekonomi dan Bisnis, \\ Universitas Katolik Soegijaranata \\ Jl. Pawiyatan Luhur IV/1 Bendan Duwur Semarang \\ email: hayu@unika.ac.id
}

\begin{abstract}
Abstrak: Kemasan merupakan salah satu elemen strategi produk yang digunakan untuk menarik konsumen membeli produk. Pengusaha kecil biasanya kurang memperhatikan kemasan produknya sehingga produk yang dijual kurang memiliki daya tarik. Di sini, perbaikan kemasan digunakan dalam membantu pengusaha mitra untuk meningkatkan penjualan produk yang dihasilkannya. Perbaikan dengan proses pendampingan ini juga mencakup pemberian label dan informasi tentang produk kepada konsumen. Para pengusaha mitra telah berhasil menjual produknya dengan harga yang sedikit lebih tinggi karena kemasan yang lebih baik
\end{abstract}

Kata kunci: . kemasan, label, makanan ringan, pemasaran, strategi produk

Abstract: Packaging is an element of product strategy that is used to attract consumers to buy the product. Small businesses usually do not pay attention to their product packages so that the products are not attractive to the target consumers. Here, we used packaging to help the small business partners to leverage sales of their products. The assistance covers labelling in which relevant information about the products is provided to the consumers. The small business partners have been successfully selling their products with higher price because of better packages.

Keywords: Packaging, labelling, snacks, marketing, product strategy

\section{PENDAHULUAN}

Suatu usaha, baik usaha besar, menengah, maupun kecil, didirikan dengan tujuan tertentu. Salah satu tujuan yang paling mendasar adalah mendapatkan keuntungan (Davoren, 2016). Menurut Zyman (2000), pemasaran merupakan cara untuk mencapai keuntungan maksimal, menjual produk sebanyak-banyaknya kepada sebanyak mungkin orang, sesering mungkin 
dengan harga setinggi mungkin. Dengan demikian, strategi pemasaran diperlukan untuk mencapai tujuan keuntungan maksimal.

Sesuai dengan mata rantai pemasaran (Arnold, 1996), keuntungan jangka panjang dapat diperoleh bila ada penggunaan produk secara berulang-ulang yang dapat terjadi bila terbentuk loyalitas pelanggan. Pelanggan akan menjadi loyal bila mereka merasakan kepuasan dari produk yang dikonsumsinya. Dengan kata lain,pengusaha harus mampu memenuhi kebutuhan dan keinginan konsumen sehingga konsumen mendapatkan kepuasan.

Produk adalah segala sesuatu yang ditawarkan ke pasar untuk digunakan, dikonsumsi yang dapat memenuhi suatu kebutuhan atau keinginan (Kotler et al, 1998). Banyak produk ditawarkan ke pasar dalam kemasan.Kemasan merupakan salah satu unsur dalam strategi produk yang dipandang memiliki posisi strategis bagi keberhasilan pemasaran suatu produk, bahkan dianggap oleh sebagian besar pemasar sebagai satu elemen bauran pemasaran tersendiri di luar 4P (product, price, promotion, place), yaitu packaging(Kotler \& Keller, 2015).

Desain kemasan yang tidak baik akan dapat membuat konsumen kesulitan di dalam mengenali dan memilih produk (Kotler \& Armstrong, 2014). Sebaliknya kemasan yang inovatif akan memberikan keuntungan bagi perusahaan dan meningkatkan penjualan.

Kotler dan Keller (2015) menyebutkan bahwa kemasan merupakan "five-second communication" dengan konsumen. Hal ini berarti bahwa kemasan menjadi daya tarik pertama produk bagi calon pembeli. Bahkan kemasan dipandang sebagai upaya untuk meningkatkan persaingan mengingat kemampuan kemasan dalam menarik konsumen, mengkomunikasikan positioning merek, hingga mendorong terjadinya pembelian (Kotler \& Armstrong, 2014).

Pengemasan (packaging) mencakup kegiatan mendesain dan menghasilkan wadah atau bungkus bagi produk (Kotler et al, 1998). Di dalamnya termasuk keputusan tentang ukuran, bentuk, bahan, warna, tulisan (pesan), dan penulisan merek. Elemen-elemen ini harus terintegrasi untuk mendorong positioning produk dan strategi pemasaran secara keseluruhan. Oleh karena itu, kemasan tidak hanya berfungsi melindungi produk tetapi juga menginformasikan citra atau kualitas dari produk dan perusahaan.

Bagi pengusaha kecil dan mikro, kemasan masih menjadi hal yang cenderung diabaikan, sehingga tidak jarang banyak usaha kecil dan mikro yang tidak dapat berkembang dengan signifikan walaupun mereka mampu menghasilkan produk yang 
relatif baik. Oleh karena itu, pengenalan terhadap pentingnya kemasan dalam meningkatkan usaha perlu dilakukan kepada para pengusaha kecil dan mikro.

Kegiatan ini dimasudkan untuk membantu pengusaha mitra yang menghasilkan makanan ringan untuk menerapkan strategi pengemasan yang mampu meningkatkan daya tarik dan penjualan produk yang dihasilkan. Hal ini mengingat bahwa dari pendampingan sebelumnya terlihat bahwa mereka tidak memperhatikan masalah pengemasan ini dan menjual produknya dengan kemasan apa adanya.

Hasil pendampingan ini diharapkan akan dapat berdampak pada peningkatan penjualan produk mereka sehingga pendapatan keluarga meningkat dan selanjutnya ekonomi rumah tanggapengusaha mitra yang tergantung pada usaha yang dijalankan juga mengalami perbaikan.

\section{RUMUSAN MASALAH}

Pengusaha mitra yang didampingi dalam kegiatan ada 4 dan berlokasi di beberapa wilayah di Semarang Utara, yaitu Kebonharjo dan Tanjung Mas. Mereka adalah pengusaha yang memproduksi makanan ringan, yaitu eggroll, bandeng, wingko babad, dan camilan kulit lunpia. Usaha dari keempat mitra tersebut masih tergolong sebagai usaha rumahan karena usaha dilakukan di rumah dan semua proses produksi dilakukan secara sendiri antara suami dan istri di antara kesibukan seharihari. Namun demikian, penghasilan dari usaha merupakan sumber yang digunakan untuk membiayai kebutuhan sehari-hari dan pendidikan anak.

Mitra yang menghasilkan eggroll menjual produknya sebagai oleh-oleh kota Semarang. Karena karakteristik produknya, eggroll termasuk makanan ringan yang relatif mahal bagi kebanyakan orang sehingga makanan ini hanya mampu menjangkau kalangan masyarakat tertentu. Namun dengan kemasan yang masih sangat sederhana, kemasan plastik dengan label stiker, membuat produk ini tidak menarik dan terkesan sangat mahal dibanding dengan tampilannya. Sebagai akibatnya, penjualan eggroll cenderung kecil dan stagnan.

Usaha wingko babad yang dilaksanakan mitra ini merupakan usaha turun temurun dari orang tua tetapi masingmasing saudara menjual dengan merek yang berbeda. Mitra menghasilkan wingko babad dengan 3 macam rasa, yaitu kelapa, pandan, dan coklat. Wingko dijual dengan kemasan kertas yang bentuk, warna, dan logo yang mirip dengan wingko yang dihasilkan pengusaha-pengusaha lain sehingga kadang sulit dibedakan dengan produk pengusaha lain. Tiap rasa ditandai dengan warna 
kemasan yang berbeda. Namun yang sering terjadi adalah warna kemasan tidak sesuai dengan rasa. Hal ini tentu dapat mengecewakan konsumen. Selain itu, tidak ada tanggal kadaluwarsa yang tercantum dalam kemasan. Padahal wingko babad merupakan produk yang tidak tahan lama, sehingga informasi tanggal kadaluwarsa ini menjadi penting.

Mitra penghasil camilan kulit lunpia berproduksi bila ada pesanan karena proses pembatannya memakan waktu yang relatif lama dan hanya dilakukan untuk mengisi waktu luang sebagai ibu rumah tangga. Produk dijual dalam kemasan plastik dengan beberapa ukuran. Belum ada label dan merek pada kemasan sehingga produk tidak dikenal secara luas. Penggunaan plastik juga membuat tampilan produk kurang menarik karena bagian dalam plastik terlihat berminyak dan remah-remah produk memberi kesan kotor.

Mitra penghasil bandeng presto juga memproduksi berdasar pesanan. Untuk pesanan dalam kota akan diantar tanpa ongkos kirim, sementara untuk pesanan luar kota akan dikirim melalui jasa pengiriman, seperti JNE. Produk bandeng dikemas dalam 2 macam kotak kardus, yaitu kemasan besar yang berisi 3 ekor ukuran besar dan kemasan kecil yang berisi 10 ekor ukuran kecil. Oleh karena belum mempunyai P-IRT, mitra belum berani menjual produknya dengan merek sendiri. Selama ini mitra bertindak sebagai mitra produsen bagi pengusaha lain yang memiliki merek.

Dari kondisi yang demikian, nampak bahwa masalah kemasan masih relatif diabaikan oleh para mitra. Padahal kemasan menjadi satu elemen penting dalam strategi produk (Kotler \& Keller, 2015) yang akan menentukan keberhasilan pemasaran. Padahal usaha makanan ringan merupakan sektor yang sangat kompetitif karena kemudahan membuka jenis usaha ini yang tidak membutuhkan modal yang besar dan ketrampilan tertentu yang spesifik. Hal ini mengundang banyak pengusaha baru masuk dan membuka usaha di bidang ini. Oleh karena itu, pengusaha makanan ringan harus mempunyai daya saing untuk bisa bertahan dalam usaha. Kemasan dapat menjadi salah satu alat yang dapat digunakan untuk maksud tersebut.

Atas dasar hal tersebut, kegiatan pendampingan ini diarahkan untuk hal-hal berikut:

1. Membantu mendesain kemasan bagi produk masing-masing mitra yang dapat meningkatkan daya tarik produk dan penjualan produk

2. Membantu mengimplementasikan desain kemasan baru pada produk

3. Mengevaluasi dampak penerapan kemasan baru terhadap penjualan. 


\section{METODE}

Kegiatan dilaksanakan dengan metode pendampingan kepada mitra dalam periode waktu 14 minggu. Pendampingan dilakukan oleh 1 dosen pendamping dan 2 kelompok mahasiswa pendamping yangmasing-masing terdiri dari 6-7orang.Masing-masing kelompok mendampingi 2 mitra.

Metode pendampingan yang diterapkan meliputi:

1. Metode wawancara dan observasi

Metode ini dilakukan pada dua minggu pertama dan dimaksudkan untuk menentukan permasalahan pemasaran yang dihadapi mitra dalam menjalankan usaha, terutama yang terkait produk dan kemasan.

2. Metode diskusi dan konsultasi

Metode ini digunakan untuk mendapat kesepakatan bentuk kegiatan antara pendamping dengan mitra dan dilakukan pada minggu ketiga. Kegiatan dimungkinkan untuk diubah atau dimodifikasi sesuai dengan kesepakatan dengan mitra. Kesepakatan dengan mitra juga dilakukan untuk menentukan skedul pelaksanaan kegiatan tiap minggu (lihat tabel 1). Skedul kegiatan dimungkinkan untuk dirubah atau disesuaikan dengan kesibukan mitra.
TABEL I

SKEDUL KEGIATAN PENDAMPINGAN

\begin{tabular}{|c|c|c|}
\hline $\begin{array}{c}\text { Minggu } \\
\text { ke- }\end{array}$ & $\begin{array}{c}\text { Metode } \\
\text { Kegiatan }\end{array}$ & Hasil Kegiatan \\
\hline $1 \& 2$ & $\begin{array}{c}\text { Wawancara } \\
\text { dan } \\
\text { observasi }\end{array}$ & $\begin{array}{c}\text { Identifikasi } \\
\text { permasalahan } \\
\text { pemasaran }\end{array}$ \\
\hline 3 & $\begin{array}{c}\text { Diskusi dan } \\
\text { konsultasi } \\
\text { Kesepakatan } \\
\text { bentuk dan skedul } \\
\text { kegiatan }\end{array}$ \\
\hline $4-7$ & $\begin{array}{c}\text { Simulasi dan } \\
\text { praktek }\end{array}$ & $\begin{array}{c}\text { Desain kemasan, } \\
\text { pengadaan, } \\
\text { Pemesanan } \\
\text { kemasan }\end{array}$ \\
\hline $8-9$ & $\begin{array}{c}\text { Simulasi dan } \\
\text { praktek }\end{array}$ & $\begin{array}{c}\text { Aplikasi kemasan } \\
\text { Pameran produk }\end{array}$ \\
\hline 10 & Eksperimen & Pambian \\
\hline $11-14$ & $\begin{array}{c}\text { Diskusi dan } \\
\text { konsultasi }\end{array}$ & $\begin{array}{c}\text { Evaluasi hasil } \\
\text { aplikasi kemasan }\end{array}$ \\
\hline
\end{tabular}

Metode ini juga digunakan untuk melakukan evaluasi atas hasil penerapan/aplikasi kemasan baru pada produk, yaitu apakah kemasan berdampak pada penjualan produk dan juga menilai kelebihan atau kekurangan dari desain kemasan.

3. Metode simulasi dan praktek

Setiap kegiatan didesain dengan melibatkan mitra dimana pendamping bertindak sebagai fasilitator. Kegiatan dilakukan bersama antara mitra dan pendamping pada waktu yang disepakati dengan mitra. Sebagian besar kegiatan dilaksanakan di rumah mitra yang juga menjadi lokasi usaha.

Desain kemasan dilakukan oleh mahasiswa pendamping dengan 
menggunakan program aplikasi komputer, seperti Coreldraw berdasarkan keinginan mitra. Draft desain dikomunikasikan dengan mitra untuk mendapatkan desain yang dikehendaki. Dalam proses ini pendampingmemberikan masukan tentang kemasan dan fungsi kemasan sebagai pertimbangan dalam membuat desain yang efektif. Desain kemasan tidak hanya mencakup ukuran, bahan, dan bentuk kemasan tetapi juga pelabelan. Informasi apa yang akan disampaikan dalam label didiskusikan bersama dengan mitra.

Pendamping juga mencari sumbersumber dimana kemasan seperti yang telah ditetapkan dapat diperoleh atau dipesan. Lokasi dan harga kemasan disampaikan kepada mitra untuk mendapat persetujuanmitra untuk pengadaan dan pemesanan. Perhitungan biaya yang muncul dari harga kemasan dan dampaknya pada harga jual produk didiskusikandengan mitra. Apabila dinilai layak, maka pengadaan atau pemesanan dilakukan.

Setelah kemasan baru siap, maka selanjutnya produk dijual dengan kemasan baru dan pada harga yang disesuaikan.

4. Metode eksperimen

Metode ini dimaksudkan untuk mengetahui dampak penerapan kemasan baru terhadap pasar, maka dilakukan penjualan produk pada pameran/bazar.

\section{HASIL PEMBAHASAN}

Berdasarkan hasil wawancara dan observasi pada minggu 1 dan 2 kepada masing-masing mitra, inventarisasi permasalahan yang terkait dengan pemasaran dan kemasan dilakukan. Permasalahan pemasaran yang muncul meliputi

- Produk, seperti rasa yang kurang enak, varian produk yang terbatas, kualitas porduk yang relatif belum baik, dan kemasan yang kurang menarik

- Ijin usaha dan P-IRT. Belum semua mitra memiliki IUMK dan/atau P-IRT, sehingga menghambat penjualan produk. Produk tidak bisa dijual di toko pusat oleh-oleh karena tidak memiliki P-IRT.

- Promosi. Tidak ada bentuk promosi tertentu yang yang dlakukan selain mengandalkan testimoni dari mulut ke mulut.

- Distribusiyang terbatas karena hanya dijual di lingkungan sekitar. Pendistribusian ke lokasi yang lebih jauh belum dimungkinkan karena distribusi yang dilakukan sendiri oleh mitra mengahadapi keterbatasan waktu dan sarana transportasi yang dimiliki mitra. 
Selanjutnya, prioritas kegiatan dan skedul pelaksanaan kegiatan ditentukan dengan cara dikomunikasikan dan didiskusikan kepada masing-masing mitra untuk mendapat persetujuan mitra.

Dari diskusi nampak mitra sangat antusias dengan masalah perbaikan kemasankarena permasalahan yang lain dinilai masalah dalam jangka yang lebih panjang. Sebagai contoh, pengadaan P-IRT terkait dengan jadwal dari Dinas Kesehatan setempat yang hanya ada dua kali dalam setahun. Sedangkan distribusi terkait dengan pengadaan sarana transportasi dan tenaga yang belum bisa dilakukan oleh mitra dalam jangka dekat. Sementara itu, masalah yang terkait dengan produk akan ditingkatkan kemudian melalui uji coba rasa dan varian. Perbaikan kemasan dan pelabelan menjadi prioritas kegiatan.

Permasalahan kemasan pada tiap mitra dan solusi yang disepakati adalah sebagai berikut:

TABEL III

PERMASALAHAN DAN SOLUSI KEMASAN

\begin{tabular}{|c|c|c|}
\hline Produk & $\begin{array}{l}\text { Masalah } \\
\text { Kemasan }\end{array}$ & $\begin{array}{c}\text { Solusi } \\
\text { Kemasan }\end{array}$ \\
\hline Eggroll & $\begin{array}{l}\text { Hanya menjual } \\
\text { dalam } \\
\text { kemasan besar } \\
\text { dengan toples. } \\
\text { Harga yang } \\
\text { relatif mahal } \\
\text { per kemasan } \\
\text { membuat } \\
\text { penjualan } \\
\text { terbatas. }\end{array}$ & $\begin{array}{l}\text { - Membuat } \\
\text { kemasan kecil } \\
\text { yang dapat } \\
\text { melindungi } \\
\text { produk dari } \\
\text { kerusakan. } \\
\text { - Mencantumka } \\
\text { n merek, logo, } \\
\text { dan komposisi } \\
\text { bahan }\end{array}$ \\
\hline
\end{tabular}

\begin{tabular}{|c|c|c|}
\hline Bandeng & $\begin{array}{l}\text { Kemasan } \\
\text { kardus tanpa } \\
\text { merek. }\end{array}$ & $\begin{array}{l}\text { - Karena alasan } \\
\text { tertentu, mitra } \\
\text { tidak ingin } \\
\text { membuat } \\
\text { merek dan } \\
\text { hanya ingin } \\
\text { mencantumka } \\
\text { n namanya } \\
\text { pada kemasan. } \\
\text { - Menambah } \\
\text { informasi } \\
\text { komposisi } \\
\text { bahan pada } \\
\text { kemasan. } \\
\text { - Tambahan } \\
\text { tersebut } \\
\text { dilakukan } \\
\text { dalam bentuk } \\
\text { stiker. }\end{array}$ \\
\hline $\begin{array}{l}\text { Wingko } \\
\text { babad }\end{array}$ & $\begin{array}{l}\text { - Kemasan } \\
\text { kertas } \\
\text { dengan } \\
\text { warna yang } \\
\text { berbeda } \\
\text { sesuai } \\
\text { dengan rasa. } \\
\text { - Ada } \\
\text { ketidaksesua } \\
\text { ian rasa } \\
\text { dengan } \\
\text { warna } \\
\text { kemasan. } \\
\text { - Belum ada } \\
\text { tanggal } \\
\text { produksi dan } \\
\text { kadaluwarsa, } \\
\text { hanya tulisan } \\
\text { kondisi baik } \\
\text { dalam } 4 \text { hari. }\end{array}$ & $\begin{array}{l}\text { - Membuat } \\
\text { kemasan } \\
\text { dengan } 1 \\
\text { macam warna. } \\
\text { - Menghilangka } \\
\text { n tulisan } \\
\text { informasi rasa } \\
\text { pada kemasan. } \\
\text { - Menyediakan } \\
\text { space untuk } \\
\text { mencantumka } \\
\text { n tanggal } \\
\text { kadaluwarsa } \\
\text { yang } \\
\text { dibubuhkan } \\
\text { dengan } \\
\text { stempel. }\end{array}$ \\
\hline $\begin{array}{l}\text { Camilan } \\
\text { kulit } \\
\text { lunpia }\end{array}$ & $\begin{array}{l}\text { Kemasan } \\
\text { dengan plastik } \\
\text { biasa tanpa } \\
\text { label dan } \\
\text { merek. }\end{array}$ & $\begin{array}{l}\text { - Memilih } \\
\text { kemasan } \\
\text { dengan bahan } \\
\text { plastik yang } \\
\text { lebih tebal } \\
\text { supaya produk } \\
\text { lebih tahan } \\
\text { lama. } \\
\text { - Memilih } \\
\text { kemasan yang } \\
\text { tidak }\end{array}$ \\
\hline
\end{tabular}




\begin{tabular}{|l|l|}
\hline & transparan \\
& untuk supaya \\
& kemasan yang \\
& berminyak \\
& tidak \\
& kelihatan. \\
& $\bullet$ Memberi label \\
& dengan \\
& informasi \\
& merek, rasa, \\
& gambar logo, \\
& dan nomor \\
& kontak \\
& pemesanan. \\
\hline
\end{tabular}

Perubahan kemasan pada masingmasing mitra setelah kegiatan ini adalah seperti pada Gambar 1.

\section{Kemasan Lama $\quad$ Kemasan Baru}

Eggrol
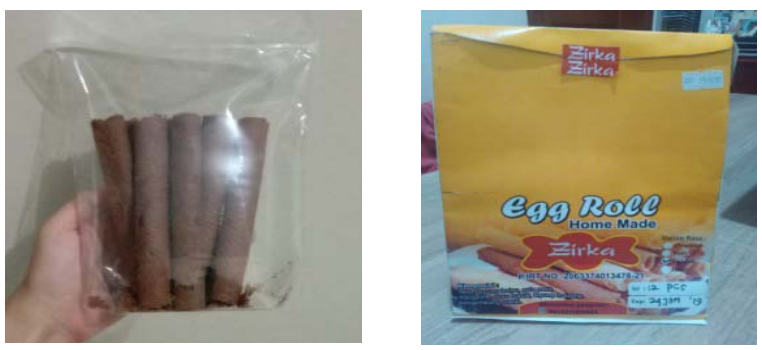

Bandeng

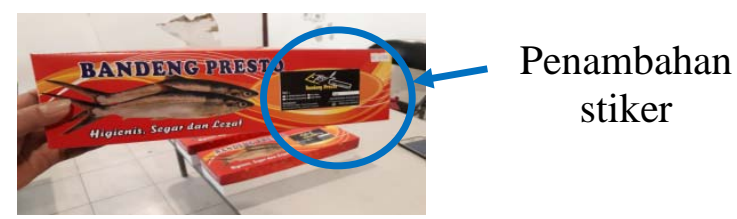

Wingko Babad
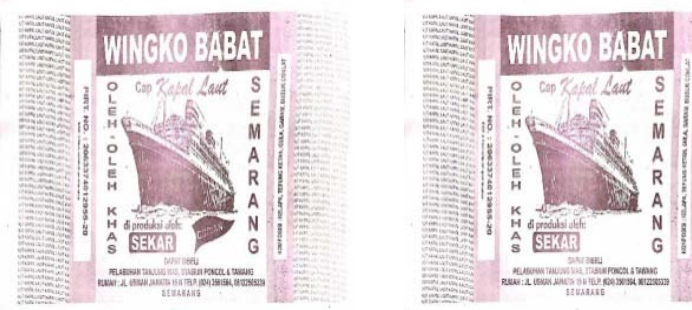

Camilan Kulit Lunpia
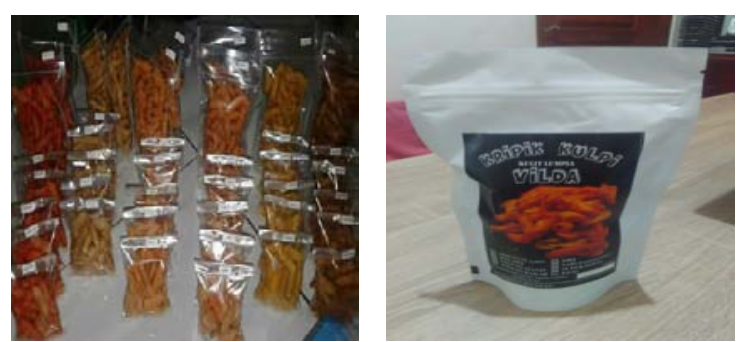

Gambar 1. Desain Lama dan Baru dari Kemasan Produk Masing-masing Mitra

Penerapan kemasan baru pada produk diujicoba dengan dua kali bazar di tempat yang berbeda. Dampak dari kemasan baru belum dapat dilihat dari bazar yang pertama karena jumlah pengunjung yang sangat sedikit. Namun demikian, antuasiasme pembeli nampak pada bazar yang kedua.
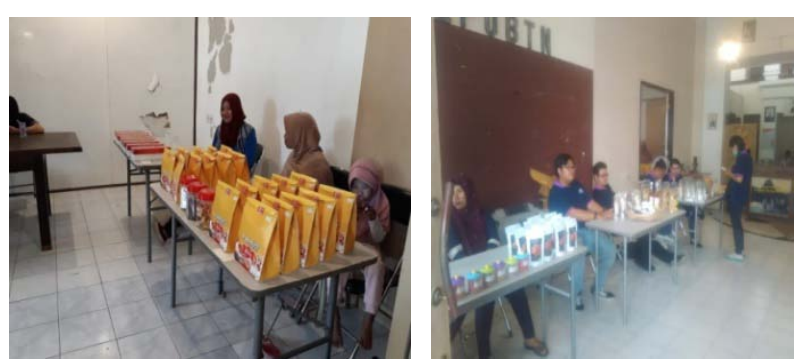

Gambar 2. Bazar Pertama Ujicoba Kemasan
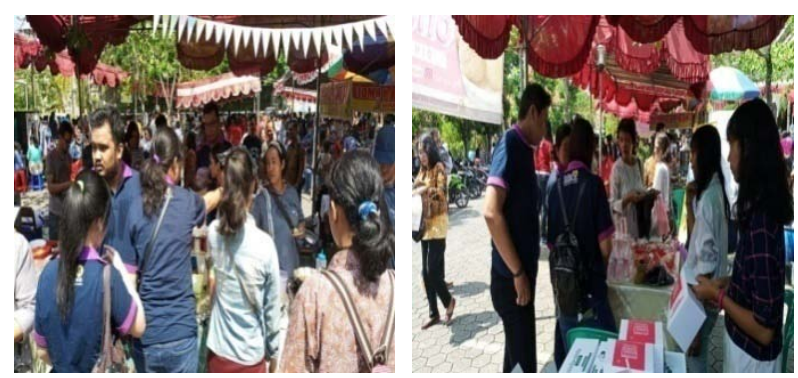

Gambar 2. Suasana Bazar Kedua

Komentar umum dari pembeli terhadap produk adalah harga yang dinilai relatif lebih murah dibandingkan dengan tampilan produk. Hal ini mengindikasikan 
bahwa kemasan telah mampu memberi positioning produk yang lebih baik. Dengan demikian, produk mempunyai kemungkinan untuk dijual dengan harga yang lebih tinggi

\section{V .SIMPULAN}

Kegiatan pendampingan perbaikan kemasan bagi para mitra berjalan dengan lancar. Antusiasme mitra dalam melaksanakan program bisa jadi disebabkan karena mereka dilibatkan sebagai penentu dan pelaksana kegiatan sehingga tidak ada keengganan dari mitra untuk menerapkan kemasan baru. Uji coba juga menunjukkan dampak positif kemasan pada positioning produk. Oleh karena itu, kemasan merupakan strategi yang dapat diterapkan oleh pengusaha kecil dan mikro pada produk mereka.

Namun demikian, perbaikan kemasan hanya merupakan salah satu elemen dari strategi produk, sehingga dampak dari kemasan terhadap keberhasilan pemasaran produk juga tergantung pada elemen bauran pemasaran lain, seperti distribusi dan promosi. Perbaikan kemasan yang dibarengi dengan promosi dan distribusi yang luas akan meningkatkan dampak positif kemasan.

Dampak kemasan yang diterapkan pada mitra ini terhadap perbaikan ekonomi keluarga belum bisa dilihat secara nyata. Hal ini membutuhkan pengamatan dalam jangka waktu yang lebih panjang. Selain itu, evaluasi pada kemasan juga harus dilakukan untuk perbaikan lebih lanjut sehingga ditemukan kemasan yang benar-benar sesuai dengan target konsumen.

\section{DAFTAR PUSTAKA}

Arnold, D. (1996). Pedoman Manajemen Merek. Surabaya: PT. Kentindo Soho. Davoren, J. (2016). 10 Most Important Business Objectives. Retrieved January 21, 2016, from Demand Media:

http://yourbusiness.azcentral.com/10important-business-objectives 3840.html

Kotler, P., \& Armstrong, G. (2014). Principles of Marketing, Fifteenth Edition. Essex, England: Pearson Education Limited.

Kotler, P., \& Keller, K. (2015). Marketing Management, 15th edition. Essex, England: Pearson.

Kotler, P., Armstrong, G., Brown, L., \& Adam, S. (1998). Marketing. Sydney, Australia: Prentice Hall Australia Pty, Ltd.

Zyman, S. (2000). The end of marketing as we know it, Matinya pemasaran. Jakarta: PT. Gramedia 